\title{
Food consumption of fish in a sub-tropical SW Atlantic ecosystem off Brazil: comparison of four Sciaenid species
}

\section{Consommation de nourriture par des poissons dans un écosystème subtropical de l'Atlantique sud-ouest au large du Brésil}

\author{
Lucy Satiko Hashimoto Soares * \\ Instituto Oceanográfico, Universidade de São Paulo, Praça do Oceanográfico, 191, Cidade Universitária, São Paulo, SP 05508-900, Brazil
}

Received 1 June 2002; revised and accepted 31 March 2003

\begin{abstract}
The first evaluations of the daily ration and population food consumption of four Sciaenid fish, under natural conditions for the Brazilian south-western Atlantic shelf $\left(23^{\circ} 35^{\prime} \mathrm{S}, 45^{\circ} 00^{\prime} \mathrm{W}\right)$ are presented. The average daily ration ranged from 4.38 to $12.92 \%$ body mass $(90 \%$ confidence interval) for the juvenile shortfin corvina (Isopisthus parvipinnis), from 0.41 to $5.52 \%$ body mass ( $90 \%$ confidence interval) for the juvenile shorthead drum (Larimus breviceps) and from $3.14 \%$ to $3.15 \%$ body mass for the juvenile whitemouth croacker (Micropogonias furnieri). Juveniles of the banded croacker (Paralonchurus brasiliensis) showed higher estimates (2.58-2.60\% body mass) than those for the adults (1.2-1.84\% body mass). The mean food consumption rate of the population was estimated at about 11 and 8 year ${ }^{-1}$, respectively, for the whitemouth croacker, and banded croacker, corresponding to a gross efficiency of 13 and $10 \%$. The estimates of daily ration were related to the feeding habits as well as to size of the fish, and probably to their specific energy budget. Estimates of population food consumption are related to population structure.

(C) 2003 Édition scientifiques et médicales Elsevier SAS and Ifremer/CNRS/IRD. All rights reserved.
\end{abstract}

\section{Résumé}

Ce travail présente la première évaluation de la ration quotidienne et de la consommation de quatre Sciénidés étudiée sur le plateau continental au large du Brésil $\left(23,35^{\circ} \mathrm{S} ; 45,00^{\circ} \mathrm{O}\right)$. La ration quotidienne moyenne varie entre 4,38 et 12,92 de masse corporelle $(90 \%$ d'intervalle de confiance) Isopisthus parvipinnis, entre 0,41 et 5,52 pour le juvénile de Larimus breviceps et de 3,14 à 3,15 pour le juvénile de Micropogonias furnieri. Les juvéniles de Paralonchurus brasiliensis présentent les valeurs plus élevées (2,58 à 2,60\% de la masse corporelle) que celles des adultes (1,2 à 1,84\%). Les taux moyens de consommation de nourriture de la population sont estimés respectivement à 11 et 8 années pour Micropogonias furnieri et Paralonchurus brasiliensis, ce qui correspond à des efficiences brutes de $13 \%$ et $10 \%$. Les rations journalières dépendent autant de l'habitat que de la taille du poisson et, probablement, de leur budget énergétique spécifique. Les estimations de la consommation sont liées à la structure de la population.

C 2003 Éditions scientifiques et médicales Elsevier SAS and Ifremer/CNRS/IRD. All rights reserved.

Keywords: Daily ration; Population food consumption; Evacuation rate; Sciaenidae; South-western Atlantic

Mots clés : Ration quotidienne ; Consommation ; Taux d'élimination ; Sciénidés ; Atlantique sud-ouest

\section{Introduction}

A review of the literature has shown that in the last years numerous studies have been undertaken, for many purposes,

\footnotetext{
* Corresponding author.

E-mail address: Isoares@usp.br (L.S.H. Soares).
}

to describe the daily ration of fish (e.g. Héroux and Magnan, 1996). This is a basic requirement to calculate the amount of food ingested by a population over a period of time relative to its biomass, and is one of the most difficult parameters to estimate. Much effort has expended in this measurement because several ecological processes depend on the amount 
of food consumed in nature. Although the objective is to arrive at an annual rate of food consumption for a given population of fish in a natural body of water, this has in fact only been achieved a few times according to Gerking (1994).

Studies are carried out in many cases for the purpose of analyzing fisheries on a multispecies basis (Sissenwine and Daan, 1991), as well as for the purpose of modeling the ecosystem (e.g. Christensen and Pauly, 1992).

The Brazilian shelf ecosystem off the northern part of the coast of the São Paulo state $\left(23^{\circ} 35^{\prime} \mathrm{S}, 45^{\circ} 00^{\prime} \mathrm{W}\right)$, in the south-western Atlantic, has been intensely studied since 1985, for the main purpose of describing the structure and functioning of a sub-tropical ecosystem. As a result, a simpler model (Rocha et al., 1998) and a more detailed model (Rocha, personal communication) have already been constructed for that ecosystem. However, as data on the food consumption of fish were unavailable, the researchers used parameters estimated by the use of an empirical model.

The purpose of this present study is to contribute to the feeding ecology of the Sciaenid fish Micropogonias furnieri, Paralonchurus brasiliensis, Isopisthus parvipinnis and Larimus breviceps in a sub-tropical system, describing their rate of gastric evacuation, daily ration and population food consumption $(Q / B)$, in order to contribute to the modeling of the ecosystem and to fisheries management on a multispecies basis.

The Sciaenid fish species constitute the most abundant family of the soft-bottom demersal fish community on the shelf ecosystem under study (Rocha and RossiWongtschowski, 1998). The key components P. brasiliensis (banded croacker), M. furnieri (whitemouth croacker), I. parvipinnis (shortfin corvina) and L. breviceps (shorthead drum) are associated with the warmer waters in this system. The croackers are believed to play an important role in the trophic flow based on detritus, and the drums in that based on phytoplankton (Soares, 1989; Amaral et al., 1994; Soares and Vazzoler, 2001).

The whitemouth croacker is of significant commercial value on the southern and southeastern Brazilian coast, and the banded croacker is fished in smaller proportion (Haimovici et al., 1997). The other two species are commercially exploited as bycatch of the bob shrimp fishery (Rodrigues and Meira, 1988).

There are several studies on the diet composition of the species under study. Field studies on diel feeding are fewer (Figueiredo and Vieira, 1998a; Manickchand-Heileman and Ehrhardt, 1996; Soares and Vazzoler, 2001). Data on evacuation rate are available for the croackers (Kurtz, personal communication; Figueiredo and Vieira, 1998b), but information on food consumption is only available for the whitemouth croaker (Manickchand-Heileman and Ehrhardt, 1996). This is the first attempt to evaluate the daily ration and population food consumption of these species under natural condition in the south-western Atlantic.

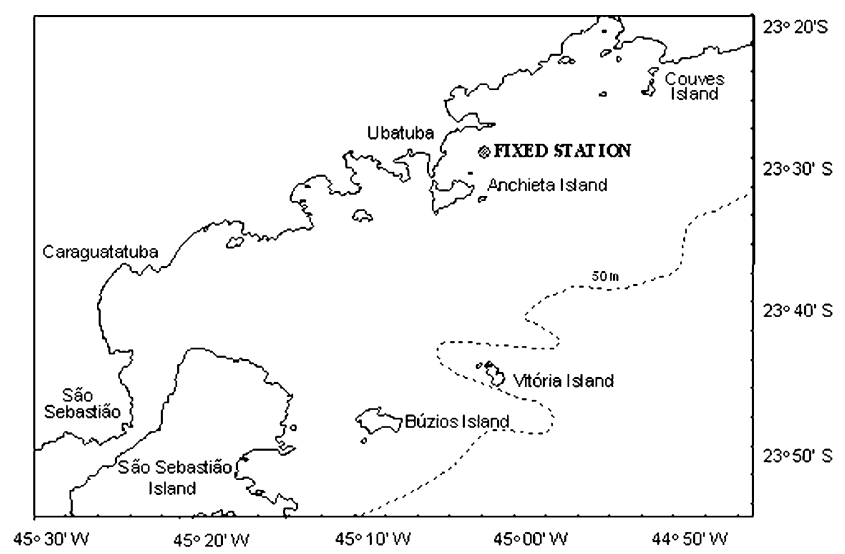

Fig. 1. The sampling locations on the southeastern Brazilian shelf off Ubatuba.

\section{Material and methods}

\subsection{Study area}

The study site is located on the inner platform of the coastal system off Ubatuba $\left(23^{\circ} 35^{\prime} \mathrm{S}, 45^{\circ} 00^{\prime} \mathrm{W}\right)$, Brazil (Fig. 1). Different water masses are present in this area during summer and winter. During summer, there is a twolayer vertical stratification due to the seasonal thermocline: the upper layer consists of warmer and less saline Coastal Water $\left(T=22-24{ }^{\circ} \mathrm{C} ; S=35-35.4\right)$ and the lower of colder South Atlantic Central Water $\left(T=14-15^{\circ} \mathrm{C} ; S=35.6-35.8\right)$. During the winter, only Coastal Water is present on the inner shelf (Castro and Miranda, 1998).

\subsection{Sampling}

Fish were sampled during a 24-h period from 4 to 5 September 1987 , at a $26 \mathrm{~m}$ deep station close to $23^{\circ} 31.5^{\prime} \mathrm{S}$ and $45^{\circ} 1.5^{\prime} \mathrm{W}$, on the Brazilian shelf off Ubatuba (Fig. 1). Fish samples were collected with a $9.7 \mathrm{~m}$ bottom trawl lined at the cod end with 25-mm mesh. Eight consecutive 30-min hauls were carried out at approximately 3 -h intervals. The time intervals 07:01-18:00 and 18:01-07:00 h were defined as day and night, respectively. The fish were immediately stored on ice on board the vessel, and taken to the laboratory within $3 \mathrm{~h}$ after being caught and put in the freezer where they were kept until processing.

\subsection{Laboratory methods}

Fish were thawed out in the laboratory and the total length to the nearest $1 \mathrm{~mm}$, the total body mass to the nearest $0.1 \mathrm{~g}$ and stomach content mass to the nearest $0.01 \mathrm{~g}$ were measured and recorded for each specimen. Specimens with signs of stomach regurgitation were excluded from the analysis. The stomachs were removed and preserved in $10 \%$ buffered formalin solution.

\subsection{Data analysis}

The stomach contents of 248 banded croacker, 132 whitemouth croacker, 95 shortfin corvina and 59 shorthead drum 
Table 1

Collection time, number $(n)$ and size range of P. brasiliensis, M. furnieri, I. parvipinnis and L. breviceps sampled during $24-\mathrm{h}$ period. Temperature: $20.2^{\circ} \mathrm{C}$ (S.D. $=0.4^{\circ} \mathrm{C}$ )

\begin{tabular}{|c|c|c|c|c|c|c|c|c|c|c|c|c|}
\hline \multirow[t]{3}{*}{ Species (common name) } & & \multicolumn{8}{|c|}{ Time (h) } & \multirow[t]{3}{*}{$(n)$} & \multirow{3}{*}{$\begin{array}{l}\text { Length range } \\
(\mathrm{mm})\end{array}$} & \multirow{3}{*}{$\begin{array}{l}\text { Mass Av. } \\
\text { (S.D.) (g) }\end{array}$} \\
\hline & & \multicolumn{8}{|c|}{ Number } & & & \\
\hline & & $07: 11$ & 09:09 & $13: 05$ & 15:08 & $18: 41$ & $21: 05$ & $24: 37$ & 03:03 & & & \\
\hline \multirow[t]{2}{*}{ P. brasiliensis (Banded croaker) } & Juv. & 40 & 4 & 40 & 18 & 33 & 20 & 26 & 9 & 190 & $70-161$ & $14.2(0.6)$ \\
\hline & Ad. & 15 & 2 & 12 & 10 & 8 & 6 & 5 & 0 & 58 & $162-217$ & $52.3(2.5)$ \\
\hline M. furnieri (Whitemouth croaker) & Juv. & 32 & 1 & 18 & 26 & 26 & 8 & 21 & 0 & 132 & $59-184$ & $27.5(1.1)$ \\
\hline I. parvipinnis (Shortfin corvina) & Juv. & 10 & 5 & 17 & 17 & 15 & 11 & 5 & 15 & 95 & $57-124$ & $4.6(0.3)$ \\
\hline L. breviceps (Shorthead drum) & Juv. & 20 & 2 & 3 & 8 & 13 & 5 & 6 & 2 & 59 & $58-100$ & $5.9(2.0)$ \\
\hline
\end{tabular}

Juv., juvenile; Ad., adult.

specimens were examined (Table 1). The daily food intake was studied for juveniles and adults of the banded croacker and for juveniles of the other three Sciaenid species.

Stomach content mass was expressed as a percentage of the total body mass (\%BM). Daily ration was estimated by the use of two commonly used models (Gerking, 1994; Cortés, 1997), suggested as being the most suitable for in situ estimates of daily food consumption. Eggers' model (Eggers, 1979) was used to compute daily ration, according to Héroux and Magnan's (1996) conclusion for in situ determination, using Maxims software (Jarre-Teichmann et al., 1992). Furthermore, this model has widely been found appropriate for species feeding on small-sized food items as is the case in this work. The formula is: $R_{\mathrm{d}}=\operatorname{avg}(W) R 24 \mathrm{~h}$.

The daily ration was also estimated using the Elliott and Persson's (1978) model, which is based on the sequential evaluation of the quantity of food consumed between each sampling period defined as: $C_{t i}=\left(\mathrm{W}_{t}-W_{0} \mathrm{e}^{-R t}\right) R t /\left(1-\mathrm{e}^{-R t}\right)$, where $W_{t}$ and $W_{0}$ are the mean amount of food (\% BM) at the beginning and at the end of the time interval, and $R$ is the instantaneous rate of gastric evacuation $\left(\mathrm{h}^{-1}\right)$. The daily ration is then computed as the sum of the amounts consumed over a 24-h period, i.e. $R_{\mathrm{d}}=\sum_{i} \quad C_{i}$.

The in situ stomach evacuation rates of shortfin corvina and shorthead drum were calculated from the reduction of the stomach contents during periods defined as non-feeding periods, by the computer program Maxims "partial model" (Jarre-Teichmann et al., 1992). This model is expressed as: $S_{t}$ $=S_{0} \mathrm{e}^{-E t}$, where $S_{0}$ is the amount of food at the beginning of the time interval, $S_{t}$ is the amount of food at time $t$ and $E$ the evacuation rate (in $\mathrm{h}^{-1}$ units).

Daily rations of the two above species were also estimated based on the $90 \%$ confidence interval of evacuation rates.

For the banded croacker and whitemouth croacker, data on banded croacker evacuation rates obtained from laboratory experiments were used (Reyna-Kurtz, personal communication), because they showed no diel pattern in the stomach content trajectory over a day and hence the rates could not be estimated. Although the evacuation rate for whitemouth croaker was available for a lagoon system (Figueiredo and Vieira, 1998b), that for the banded croacker was used due to the higher similarity of its diet to that of the whitemouth croaker in the system under study.
The rate of population food consumption $Q / B$ (in per time units), the number of times a population consumes its own weight, was estimated with Maxims software (JarreTeichmann et al., 1992) based on the gross food conversion efficiency and growth parameters using a version of Pauly's (1986) model, in which:

$$
Q / B=\text { food consumption/biomass }=\frac{\int_{t_{\mathrm{r}}}^{t_{\max }} \frac{(\mathrm{d} w / \mathrm{d} t) N_{t}}{K_{1(t)}} \mathrm{d} t}{\int_{t_{r}}^{t_{\max }} W_{t} N_{t} \mathrm{~d} t}
$$

where $t_{\mathrm{r}}$ is the age at entry, and $t_{\max }$ the age of exit from the population, $N_{t}$ the population size, $K_{1(t)}$ the gross food conversion efficiency at age $t$, and $W_{t}$ the weight at age $t$. $Q / B$ is, then, the number of times the population in question consumes its own weight, per year. Fish are assumed to follow the von Bertalanffy function (VBGF).

The $Q / B$ equation was originally derived from estimates of gross food-conversion efficiency, defined for a given range of size and a given time interval as $\mathrm{K} 1=$ growth increment/food consumed and generalizing it, the rate of food consumption $=$ growth rate/K1 .

The gross food conversion efficiency is assumed to depend on weight $(W)$ according to equation $\mathrm{K} 1=1-\left(W / W_{\infty}\right)^{\beta}$, where the asymptotic weight $\left(W_{\infty}\right)$ is the mean weight of extremely old specimen in a population of fish growing according to VBGF, The equation above implies that K1 approaches 1 as $W$ approaches $0 . \beta$, as defined in the above formula, express different values of K1 combined with an estimate of $W_{\infty}$ pertaining to a natural population of fish.

Eggers' daily ration estimates were used for population food estimation, in accordance with Héroux and Magnan's (1996) conclusions. The growth and mortality parameters, available for Ubatuba system, estimated by Soares (unpublished data), Peria (personal communication) and Pinter (personal communication) were used for the estimation of the population food consumption of shortfin corvina, banded croacker and whitemouth croacker, respectively. This rate was not estimated for shorthead drum because the required parameters were not available for this species. 


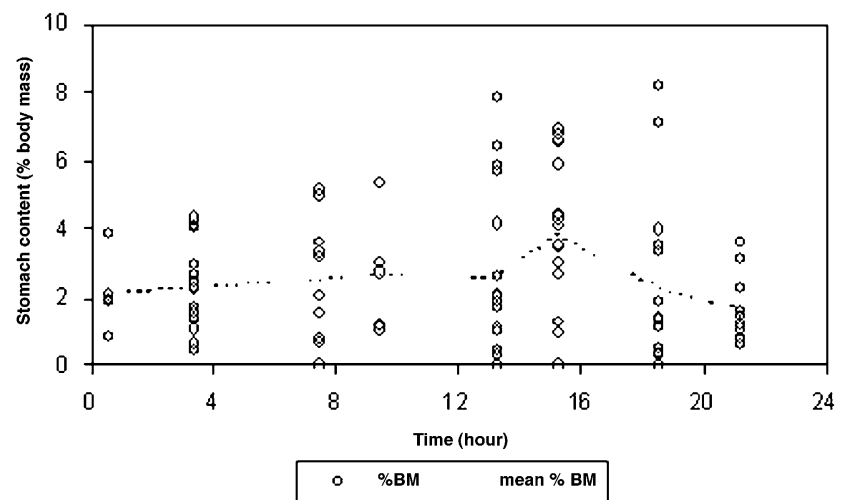

Fig. 2. Time trajectory of stomach contents of juvenile I. parvipinnis (shortfin corvina) sampled during 4-5 September 1987.

\section{Results}

The trajectories of the stomach content fullness are shown in Figs. 2-5. Shortfin corvina presented the highest stomach fullness values during the morning and afternoon (Fig. 2) and shorthead drum from early evening to around midnight (Fig. 3). Neither the banded nor the whitemouth croacker showed any clear pattern of diel periodicity of food intake (Figs. 4 and 5). Shortfin corvina (Fig. 2) had the largest and the banded croacker the smallest range and values of fullness (Fig. 5).

Table 2 shows the estimated evacuation rate, the period of gastric evacuation and the daily ration for shortfin corvina and shorthead drum juveniles. The non-feeding interval of shortfin corvina $(7 \mathrm{~h})$ began in the afternoon and ended during the evening. For shorthead drum it began in the evening and lasted $12 \mathrm{~h}$. The estimates of total daily intake obtained by two methods ranged from $4.38 \%$ to $12.92 \%$ confidence interval for shortfin corvina, and between 0.41 and 5.54 for shorthead drum.

For both croackers the estimates obtained using the two methods were closely similar. The daily ration estimates ranged between $2.58 \%$ and $2.60 \%$ for the juvenile banded croacker (60-161 mm) and between $1.82 \%$ and $1.84 \%$ for the adults (162-217 mm) (Table 3). For juvenile whitemouth croacker the daily rations varied from $3.14 \%$ to $3.15 \%$.

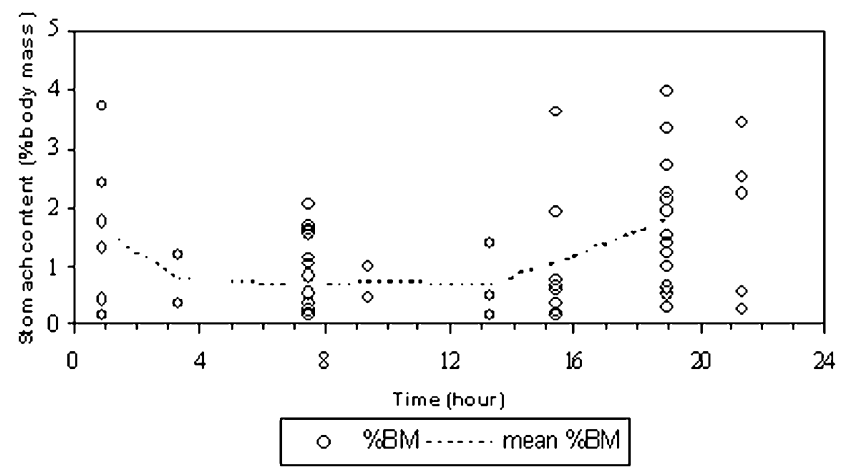

Fig. 3. Time trajectory of stomach contents of juvenile L. breviceps (shorthead drum) sampled during 4-5 September 1987.

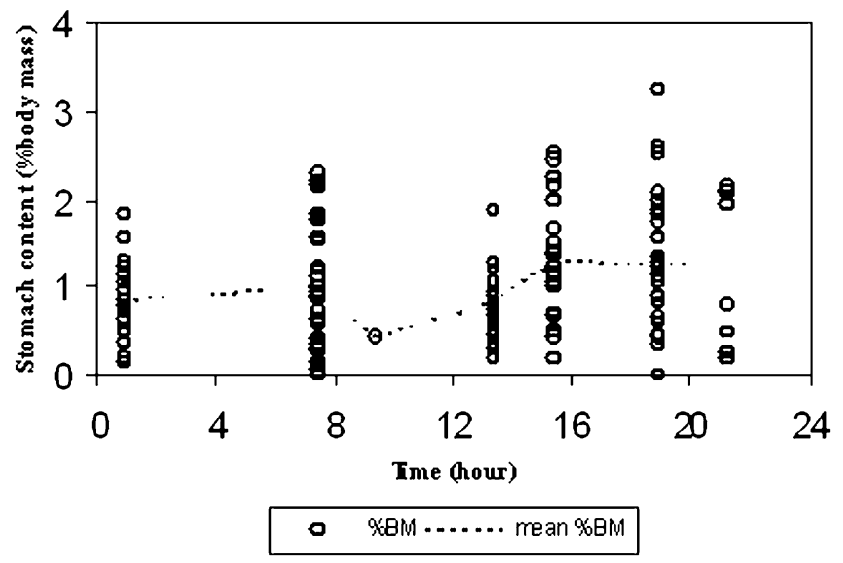

Fig. 4. Time trajectory of stomach contents of juvenile $M$. furnieri (whitemouth croacker) sampled during 4-5 September 1987.

Table 4 gives our estimates of the croacker and shortfin corvina annual population food consumption as well as their population growth and mortality parameters. The food consumption $(Q / B)$ of the whitemouth croacker population was 11 year $^{-1}$, or $3 \%$ day $^{-1}$, yielding a gross efficiency (ratio of production to consumption) of $9.9 \%$. The banded croacker population's estimated consumption was a little lower $(Q / B=$ 8.3 year $^{-1} ; 2.3 \%$ day $^{-1}$ ) than that of the whitemouth croacker, but the gross efficiency was higher. Shortfin Corvind showed the highest value of Q/B (15.5-45.8 year $^{-1} 90 \%$ confidence interval) and the lowest gross efficiency (2.3-6.9\%).
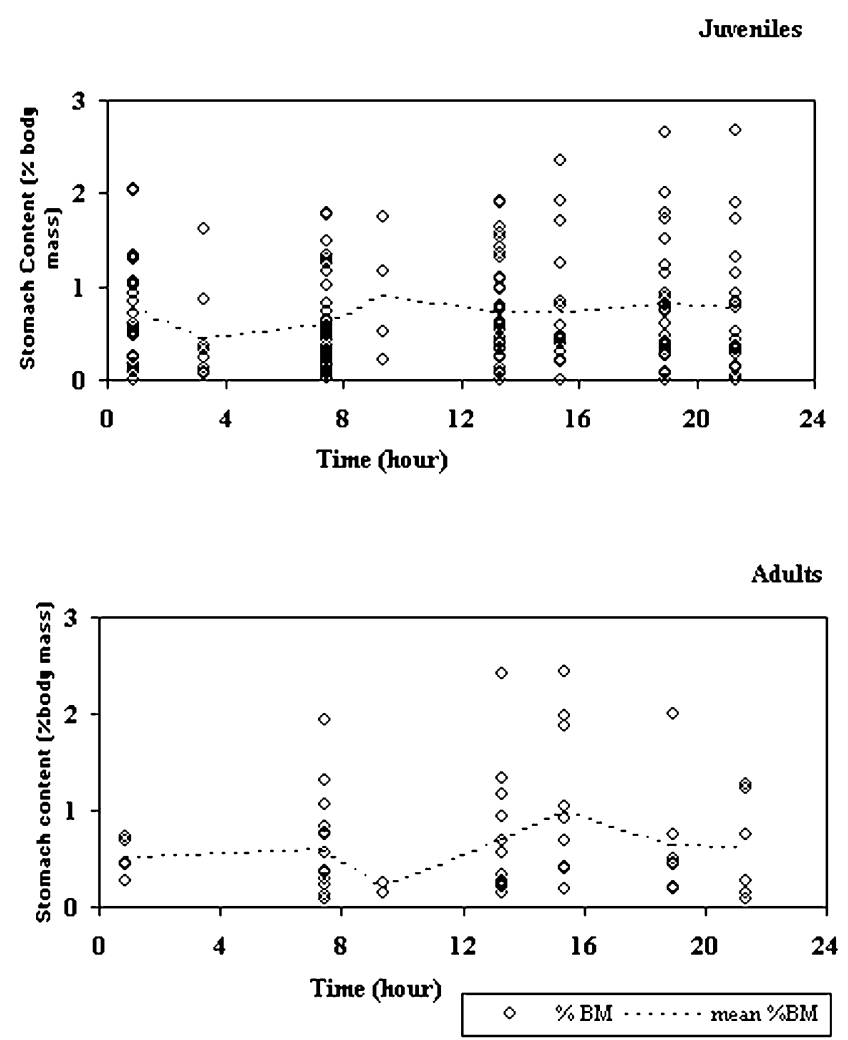

Fig. 5. Time trajectory of stomach contents of juvenile (above) and adult $P$. brasiliensis (banded croacker) sampled during 4-5 September 1987. 
Table 2

Estimates of evacuation rate $\left(\mathrm{h}^{-1}\right)$ and daily ration (\% body mass per day) of I. parvipinnis and L. breviceps

\begin{tabular}{|c|c|c|c|c|c|c|}
\hline \multirow[t]{2}{*}{ Species } & \multicolumn{2}{|l|}{ Evacuation rate } & \multirow[t]{2}{*}{ d.f. } & \multirow[t]{2}{*}{$r^{2}$} & \multicolumn{2}{|c|}{ Daily ration (\% body wet mass per day) } \\
\hline & Nonfeeding interval (h) & $\begin{array}{l}\text { Evacuation rate }\left(\mathrm{h}^{-1}\right), 90 \% \\
\text { CI }\end{array}$ & & & Eggers (1979), 90\% CI & $\begin{array}{l}\text { Elliott and Persson (1978) } \\
90 \% \text { CI }\end{array}$ \\
\hline \multirow[t]{3}{*}{ I. parvipinnis } & $15-22$ & 0.073 & 1 & $0.99 *$ & 4.40 & 4.38 \\
\hline & & 0.144 & & & 8.67 & 8.65 \\
\hline & & 0.215 & & & 12.95 & 12.92 \\
\hline \multirow[t]{3}{*}{ L. breviceps } & $20-8$ & 0.015 & 2 & $0.83 * *$ & 0.41 & 0.41 \\
\hline & & 0.108 & & & 2.98 & 2.97 \\
\hline & & 0.201 & & & 5.54 & 5.52 \\
\hline
\end{tabular}

* Significant, $P<0.05$

* $*$ Significant, $P<0.10$

\section{Discussion and conclusion}

The rate of food consumption is determined by the availability of food and the motivational state of the fish. It is affected by temperature and other abiotic factors, by body size and by the physiological condition of the fish (Wooton, 1995)

Temperature has an important effect on the food intake of fish belonging to different climate zones, having the greatest effect on the metabolic rate in exothermic animals. Our estimates of the daily rations of the four Sciaenid species ranged from $1.8 \%$ to $10 \% \mathrm{BM}$, which are, on average, within the range of the values of tropical fish, according to the figures given by Pandian and Vivekanadan (1985) in plotting data on 44 temperate and tropical fish species. This is in accordance with the bottom water winter temperature in the system under study around $20^{\circ} \mathrm{C}$.

The general pattern of the daily ration per unit fish mass, which decreases with the mass (Calow, 1985), could be registered in this study as in the case of the banded croacker, the juveniles of which presented a higher ration (1.4x) than that of the adults. This is in accordance with the results of the oxygen consumption tests performed for this species in the laboratory (Phan et al., 1993).

The daily rations estimated for the juveniles of the two croacker species are of the same order of magnitude, and are probably related to their similar energy expenditure, which is expressed by a similar body morphology as well as in a similar diel feeding pattern and similar food habits. They are both benthic feeders feeding mainly, according to many authors, on polychaetes (e.g. Soares and Vazzoler, 2001, and references cited there).

A very similar value $(3.4 \% \mathrm{BM})$ to that of our juvenile whitemouth croacker estimates was found as an optimum daily ration for juveniles (13-16 cm TL; 32-45 g TM) of this species at $15.0 \pm 1.4{ }^{\circ} \mathrm{C}$, in a laboratory experiment by Aristizabal-Abud et al. (1992). For the larger sized female specimens (29.1-54.3 cm total length) from Trinidad, West Indies, Manickchand-Heileman and Ehrhardt (1996) also

Table 3

Estimates of daily ration (\% body wet mass day $\left.{ }^{-1}\right)$ obtained for $P$. brasiliensis and M. furnieri. Evacuation rate, $E=0.126 \mathrm{~h}^{-1}\left(\mathrm{Kurtz}_{\mathrm{r}} 1993\right)$

\begin{tabular}{llll}
\hline & P. brasiliensis & & M.furnieri \\
\cline { 2 - 4 } & Juveniles & Adults & Juveniles \\
\hline Eggers (1979) & 2.60 & 1.84 & 3.15 \\
Elliott and Persson (1978) & 2.58 & 1.82 & 3.14 \\
\hline
\end{tabular}

Table 4

Estimation of population food composition based on size-specific daily rations from stomach contents sampled at sea

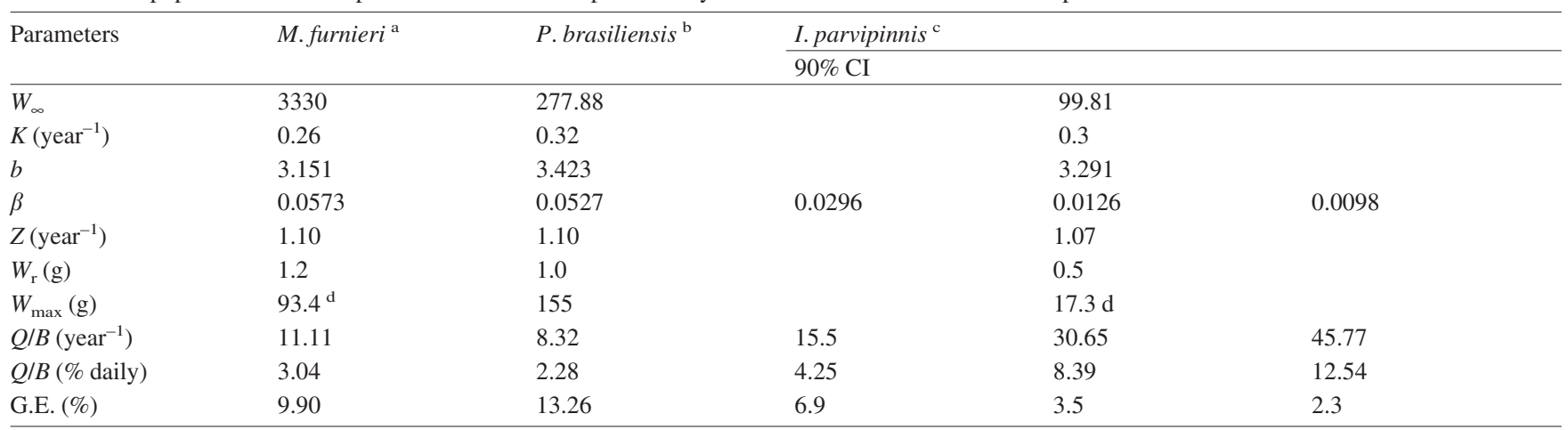

${ }^{a}$ Pinter (personal communication).

${ }^{\mathrm{b}}$ Peria (personal communication).

${ }^{\mathrm{c}}$ Soares (personal communication).

${ }^{\mathrm{d}}$ Max. weight of the juvenile specimens in the sample from observed population. 
reported a similar value $(3.45 \% \mathrm{BM})$, based on field data. Besides geographical and oceanographical variations, this last result can be related to the higher gastric evacuation rate estimated by the authors $\left(0.27 \mathrm{~h}^{-1}\right)$ and to the different diel feeding pattern presented by that population.

The juveniles of shortfin corvina, a pelagic feeder (Soares and Vazzoler, 2001), showed the highest daily ration values. This is in accordance with the literature, which has reported higher energy expenditure and consequently higher consumption for pelagic fish (e.g. Pauly, 1989; Sambilay, 1990). Nevertheless, for the juveniles of the shorthead drum (Soares and Vazzoler, 2001), the diet of which is similar to that of the shortfin corvina, the estimated rations are close to those of the croackers, which can be related to a specific energy budget.

The $Q / B$ of the three species estimated in this work are within the range of the 75 values for 56 temperate and tropical marine species found by Pauly (1989) in the scientific literature. Their location within the range shows again the effect of temperature on population food intake, since only above $20{ }^{\circ} \mathrm{C}$ there is a greater variance, including values similar to those for the shortfin corvina $(Q / B=30.7$ on a average). The highest value for the shortfin corvina can be related to water temperature, ontogenetic phase of the juvenile population, as well as to its energy expenditure as a pelagic predator. The higher $Q / B$ of the whitemouth croacker as compared to that of the banded croacker can be explained by its population structure, mainly composed, in the system under study, of juveniles (Rocha and Rossi-Wongtschowski, 1998).

Although low, the gross efficiency rates of the croacker species are within the 10-25\% range considered by Brett and Groves (1979) for juvenile fish prior to maturity, and are of the same order of magnitude as the available estimates for the whitemouth croaker (Aristizabal-Abud et al., 1992; Manickchand-Heileman and Ehrhardt, 1996). The estimated gross efficiency of the shortfin corvina was very low, but considering the confidence interval there is in the range between 5\% and 30\% available for fish (Christensen et al., 2000).

The $Q / B$, and consequently G.E. estimates are in dependence on mortality rate and VBGF parameters used in the calculation. The published data on these parameters for the croackers are in range of the used data here (Frose and Pauly, 2003). The low values could been resulted from the $W_{\max }$ values used, which in the case of whitemouth croacker and shortfin corvina were those obtained from the juvenile population of Ubatuba system.

The estimates of daily ration were related to the feeding habits as well as to size of the fish, and probably to their specific energy budget. Estimates of population food consumption are related to population structure. The data obtained should contribute to our rather limited knowledge of the food consumption of tropical marine teleosts and be useful in the modeling trophic interactions of the marine ecosystem of the sub-tropical south-western Atlantic.

\section{Acknowledgements}

The author wishes to thank the Interministerial Commission of Brazilian Marine Resources (CIRM) which made this project possible by their financial support of the integrated project "Utilização Racional dos Ecossistemas Costeiros da Região Tropical Brasileira-Estado de São Paulo". The author is also grateful to the Brazilian Research Council CNPq (Science and Technology Ministry of Brazil) for the productivity grant (Proc. No. 523249/96-9). Special thanks are further due to Professor Dr. Luiz Alberto Zavala-Camin, for his courtesy in reading the final manuscript. Finally, our thanks to the anonymous referee for the valuable suggestions.

\section{References}

Amaral, A.C.Z., Nonato, E.F., Petti, M.A.V., 1994. Contribution of the polychaetous annelids to the diet of some Brazilian fishes. In: Dauvin, J.C., Lauvier, L., Reish, D.J. (Eds.), Actes de la 4 e Conférence Internationale de Polychètes, 162. Mém. Mus. Natn. Hist. Nat., Paris, pp. 331-337.

Aristizabal-Abud, E.O., Prenski, L.B., Daleo, G.R., 1992. Growth and energy in juvenile croacker (Micropogonias furnieri (Desmarest 1823)). ICES J. Mar. Sci. 49, 65-68.

Brett, J.R., Groves, T.D.D., 1979. Physiological energetics. In: Hoar, W.S., Randall, D.J., Brett, J.R. (Eds.), Fish Physiology, 8: Bioenergetics and Growth. Academic Press, New York, pp. 279-352.

Cortés, E., 1997. A critical review of methods of studying fish feeding based on analysis of stomach contents: application to elasmobranch fishes. Can. J. Fish. Aquat. Sci. 54, 726-738.

Calow, P., 1985. Adaptive aspects of energy allocation. In: Tytler, P., Calow, P. (Eds.), Fish Energetics: New Perspectives. Croom Helm, Sydney, pp. 13-31.

Castro, B.M., Miranda, L.B., 1998. Physical oceanography of the western Atlantic continental shelf locate between 4 and $34^{\circ} \mathrm{S}$ coastal segment (4, W). In: Robinson, A.R., Brink, K.H. (Eds.), The Sea Wiley, pp. 209-252.

Christensen, V., Pauly, D., 1992. ECOPATH II-a software for balancing steady-state models and calculating network characteristics. Ecol. Model. 61, 169-185.

Christensen, V., Walters, C.J., Pauly, D., 2000. Ecopath with Ecosim: A User's Guide. October 2000 edition. Fisheries Centre, University of British Columbia, Vancouver, ICLARM, Penange, Malaysia.

Eggers, D.M., 1979. Comments on some recent methods for estimating food consumption by fish. J. Fish. Res. Bd. Can. 34, 290-294.

Elliott, J.M., Persson, L., 1978. The estimation of daily rates of food consumption for fish. J. Anim. Ecol. 47, 977-991.

Figueiredo, G.M., Vieira, J.P., 1998a. Cronologia alimentar da corvina, Micropogonias furnieri, no estuário da Lagoa dos Patos, RS, Brasil. Atlântica 20, 55-72.

Figueiredo, G.M., Vieira, J.P., 1998b. The evacuation rate of whitemouth croacker, Micropogonias furnieri under semi-experimental conditions. Atlântica 20, 131-139.

Frose, R., Pauly, D., 2003. Fishbase. World Wide Web electronic publication. http://www.fishbase.org. Available from version 26 February 2003.

Gerking, S.D., 1994. Feeding Ecology of Fish. Academic Press, San Diego.

Haimovici, M., Castello, J.P., Vooren, C.M., 1997. Fisheries. In: Seeliger, U., Odebrecht, C., Castello, J.P. (Eds.), Subtropical Convergence Environments, the Coast and Sea in the Southwestern Atlantic. Springer, Heidelberg, pp. 183-196.

Héroux, D., Magnan, P., 1996. In situ determination of food daily ration in fish: review and field evaluation. Environ. Biol. Fishes 46, 61-74. 
Jarre-Teichmann, A., Palomares, M.L., Soriano, M., Gayanilo Jr., F.C., Pauly, D., 1992. A User's Manual for MAXIMS (Version 1.0): A Computer Program for Estimating the Food Consumption of Fishes from Diel Stomach Contents Data and Population Parameters. ICLARM Software 4. Manila, International Center for Living Aquatic Resources Management. pp. 28.

Manickchand-Heileman, S.C., Ehrhardt, N.M., 1996. Energy budget of female whitemouth croacker Micropogonias furnieri, determined from field data in Trinidad, West Indies. Bull. Mar. Sci. 58, 385-392.

Pandian, T.J., Vivekanadan, E., 1985. Energetics of feeding and digestion. In: Tyler, P., Calow, P. (Eds.), Fish Energetics. New Perspectives. Croom Helm, London, pp. 99-124.

Pauly, D., 1986. A simple method for estimating the food consumption of fish populations from growth data and food conversion experiments. Fish. Bull. US 84, 827-840.

Pauly, D., 1989. Food consumption by tropical and temperate fish populations: some generalizations. J. Fish Biol. 35 (Suppl. A), 11-20.

Phan, V.N., Gomes, V., Morais, D.M., Passos, M.J.A.C.R., 1993. Estudo bioenergético de animais marinhos costeiros. I. Paralonchurus brasiliensis (Perciformes: Sciaenidae). Publção esp. Inst. Oceanogr. São Paulo (10), 199-215.
Rocha, G.R.A., Gasalla, M.A., Rossi-Wongtschowski, C.L.D.B., Soares, L.S.H., Pires-Vanin, A.M., Muto, E.Y., Cergole, M.C., Aidar, E., Mesquita, H.S., Gianesella-Galvão, S.F., Véga-Perez, L.A., Jarre-Teichmann, A., 1998. Quantitative Model of trophic interactions in the Ubatuba shelf system (Southeastern Brazil). NAGA, ICLARM Q 21, 25-32.

Rocha, G.R.A., Rossi-Wongtschowski, C.L.D.B., 1998. Demersal fish community on the inner shelf of Ubatuba, south-eastern Brazil. Rev. Bras. Oceanogr. 46, 93-109.

Rodrigues, E.S., Meira, P.T.F., 1988. Dieta alimentar de peixes presentes na pesca dirigida ao camarão-sete-barbas (Xiphopenaeus kroyeri) na Baía de Santos e Praia do Perequê, Estado de São Paulo, Brasil. Bol. Inst. Pesca, São Paulo 15, 135-146.

Sambilay Jr., V.C., 1990. Interrelationships between swimming speed, caudal fin aspect ratio and body length of fishes. Fishbyte 8, 16-20.

Sissenwine, M.P., Daan, N., 1991. An overview of multispecies models relevant to management of living resources. ICES Mar. Sci. Symp. 193, 6-11.

Soares, L.S.H., 1989. Alimentação de Isopisthus parvipinnis (Teleostei: Sciaenidae) na Baía de Santos, São Paulo. Bolm Inst. Oceanogr., São Paulo 37, 95-105.

Soares, L.S.H., Vazzoler, A.E.A.M., 2001. Diel changes in food and feeding activity of Sciaenid fishes from the south-western Atlantic, Brazil. Revta Brasil. Biol. 61, 197-216.

Wooton, R.J., 1995. Ecology of Teleost Fishes. Chapman \& Hall, London. 